\title{
Audit Quality Attibutes and Client Factors
}

\section{Muhamad Taqi ${ }^{1}$, Rahmawati $^{2}$, Bandi $^{2}$, Sri Murni ${ }^{2}$, Warsina $^{3}$}

${ }^{1}$ Economics and Business Faculty, University of Sultan Agung Tirtayasa, Tangerang

J1. Darmawangsa Raya No. 32 Tangerang, 15138, Indonesia

${ }^{2}$ Department of Management Faculty of Economics and Business Universitas Sebelas Maret, Indonesia

J1. Ir. Sutami 36 Surakarta, 57126, Indonesia

${ }^{3}$ Doctoral Student of Economics, Uiversitas Seberlas Maret, Indonesia

J1.Ir. Sutami 36 Surakarta, 57126, Indonesia

\section{Info Artikel}

Keywords:

Audit quality; Auditor Specialization; Detecting misstatement; Reporting misstatement; and Firm Reputation.

ISSN (print) : 2598-7763 ISSN (online): 2598-7771

$\triangle$ Corresponding Author: Muhammad Taqi: Tel. /Fax. +62 877-7101-1961 E-mail: muhamad.taqi@yahoo.com (c) BY-NC-SA

\begin{abstract}
Abtract
This study aims to examine and provide empirical evidence of the impact of client size and industry specialization on audit quality and the effect of audit quality on audit fees, reputation, and litigation both on audit-detecting misstatement quality and audit-reporting misstatement quality-analyzed based on client factors. This paper utilizes the perspective regulatory theory and signaling theory and is based on quantitative-causality research conducted by the survey method. Technique sampling is performed by purposive sampling. The results indicate that client size had a significant positive effect on the audit qualitydetecting misstatement but does not have any impact on the audit quality-reporting misstatements whereas industry specialization auditors have no effect on the audit qualitydetecting misstatement but have a significant effect on the audit quality-reporting misstatements. Clients may opt for the auditor that charges lower fees but can provide a positive signal for stakeholders or choose an auditor that is registered with BPK or OJK because such audit firms are more acceptable by stakeholders. As for the external auditors, the highquality audit is necessary to avoid the risk of litigation in addition to maintaining independence.
\end{abstract}

Citation: Taqi, M., Rahmawati, Bandi, Murni, S., and Warsina. (2020). Audit Quality Attibutes and Client Factors. AFRE Accounting and Financial Review, 3 (1)

\begin{abstract}
Abstraks
Penelitian ini bertujuan untuk menguji dan memberikan bukti empiris dari dampak ukuran klien dan spesialisasi industri pada kualitas audit dan pengaruh kualitas audit terhadap biaya audit, reputasi dan litigasi baik pada kualitas salah saji pendeteksi audit dan kualitas salah saji pelaporan audit dianalisis berdasarkan faktor klien. Penelitian ini menggunakan teori pengaturan perspektif dan teori sinyal dan didasarkan pada penelitian kausalitas kuantitatif yang dilakukan dengan metode survei. Teknik pengambilan sampel dilakukan dengan purposive sampling. Hasil penelitian menunjukkan bahwa ukuran klien memiliki efek positif yang signifikan pada salah saji deteksi kualitas audit tetapi tidak memiliki dampak pada salah saji pelaporan kualitas audit sedangkan auditor spesialisasi industri tidak berpengaruh pada salah saji deteksi kualitas audit tetapi memiliki efek signifikan tentang salah saji pelaporan kualitas audit. Klien dapat memilih auditor yang membebankan biaya lebih rendah tetapi dapat memberikan sinyal positif bagi pemangku kepentingan atau memilih auditor yang terdaftar di BPK atau OJK karena perusahaan audit tersebut lebih dapat diterima oleh pemangku kepentingan. Sedangkan untuk auditor eksternal, audit berkualitas tinggi diperlukan untuk menghindari risiko litigasi selain menjaga independensi.
\end{abstract}

JEL Classification: M42, M41, G02

DOI: https://doi.org/10.26905/afr.v3i1.3884 


\section{INTRODUCTION}

The recent disclosure of buying and selling audit opinions involving the BPK RI auditors with the Ministry of Villages, Development of Disadvantaged Regions and Transmigration (Kemendes PDTT) and besides the audit of Jasa Marga Purbaleunyi (Harley Davidson's bribery case) that took place in 2017 suggest that the credibility of audit reports from Indonesia's reputable institutions are in doubt. Furthermore, in the context of external auditors (KAP), there are incidents involving audit firms being censured by the Ministry of Finance culminating in bans from 3 months up to 1 year from practicing with some firms having their licenses revoked. These events suggest that the auditor's reputation is deteriorating and the auditing profession is prone to litigation threats.

The threat of litigation may occur as a result of accepting dubious clients with low levels of integrity. Unethical clients from large-scale companies will pressure non-big 4 auditors when determining audit fees and the final audit report. This condition can be overcome if the external auditors maintain their independence, adhere to auditing standards, and possess an appropriate quality control system. Other efforts that can be undertaken by the auditors to improve audit quality include soliciting auditors that specialize in specific industries. These characteristics are in line with the Public Accountant Professional Standards relating to audit firm quality control standards (SPAP Per 31 March 2011 PSPM Section 200: 17000.1-17000.9 concerning the assignment of personnel and employment). The auditor's efforts are expected not only to improve audit quality but will result in higher audit fees, a better reputation and consequently lowering litigation risk.

The decrease in audit quality occurs when the auditor is forced to accept low audit fees resulting in the audit firm reducing the audit hours, the number of personnel in the audit team, and omitting major procedures in the audit process. The Regulation of the Board of Public Accountants of Indonesia (IAPI) number 2 of 2016 attachment IV has mandated a minimum tariff of audit fee of Rp. 60 million. In reality, however, many audit firms in Indonesia are compelled to accept clients below the minimum tariff and therefore partners will strategize to reduce costs resulting in lower audit quality. Such compulsion is one form of client pressure on the auditor at the be- ginning of the audit and disrupts the auditor's efforts in maintaining an appropriate level of audit quality. It also gives rise to a perspective that in Indonesia, the topic of audit quality is very much an area of interest. In addition to low audit fees that auditors are forced to accept, conflicts of interest and ambiguity will result in the erosion of the auditor's independence and the critical deterioration of partners in auditing judgments (Carrey and Simnett 2006), (Mgbame, Eragbhe, \& Osazuwa, 2012), (Kalabeke, Sadiq, \& Keong, 2019), (Atmojo \& Sukirman, 2019) can be utilized by larger clients to lobby for the final audit outcome. In addition, the auditor/client's economic bonding, auditor financial dependence on the client (Hoitash, Markelevich, and Barragato, 2007) and the bounded rationality factor are also some other causes that may influence the audit outcome (Fischbacher \& Stefani, 2007), (Anastasopoulos \& Anastasopoulos, 2012), (Tan \& Yim, 2014). Hence, the above findings suggest that factors affecting the client have an impact on audit quality.

Other than the auditor attributes, factors determining audit quality are inherent risk and control risk within the client (Arrens, Elder and Beasley, 2012; Elder, Beasley, Arens, and Yusuf, 2011) and Al-Thuneibat, Al Issa, and Baker (2011), (Al-Thuneibat, Al Issa, \& Ata Baker, 2011), (Benson, Clarkson, Smith, \& Tutticci, 2015), (Alsmairat, Yusoff, \& Ali, 2019), (Almarayeh, Aibar-Guzmán, \& Abdullatif, 2020) conclude that clients who have a good reputation in producing reliable financial statements and management with high integrity and competence will instill confidence or trust within the audit team. The existence of factors other than auditor's characteristics that determine the audit quality is in line with the research outcomes of Anis (2014). However, this is contrary to DeAngelo's (1981) and Watkins et al. (2004), (Deshmukh \& Zhao, 2020) findings that audit quality resides with the auditors themselves. These conflicting findings provide further research opportunities for audit quality. To fill the gaps and opportunities of this study, this study will test the antecedent variable and the consequences of audit quality based on factors affecting the auditors and clients using the perspective of regulatory theory and signaling theory. Operationally this research aims to test and provide empirical evidence on company size effect on audit quality as well as audit quality effect on litigation and company value.

This study is different from prior studies as 
it will not only test the effect of the influence of auditors but also the client's influence on audit quality. In addition, the originality lies in the theories used, the development of hypotheses and empirical research models tested, as well as the location of this study. Location differences are important in audit quality research because interstate differences may result in differences in legal systems and legislation applicable in the country (Francis, 2004). Similarly, geographical locations may also have an impact on audit quality (Choi, Kim, Qiu, \& Zang, 2012), (Cook et al., 2019)

This study aims to examine and provide empirical evidence of the impact of client size and industry specialization on audit quality and the effect of audit quality on audit fees, reputation, and litigation both on audit-detecting misstatement quality and audit-reporting misstatement quality-analyzed based on client factors

\section{HYPOTESIS DEVELOPMENT}

\section{Effect of Client Company Size on Audit Quality}

Audit risk comprising of inherent risk and control risk originates from the client (Elder, Beasley, and Arens, 2011). As such, some research has link audit quality with factors associated with the client. Fernando et al. (2010), (Durham, 2003), and (Laura \& Darmawan, 2019) find that there is an association of audit quality to client size and equity capital costs. Besides, Chen et al. (2008) also attribute the importance of clients with audit quality. Leventis and Caramanis (2005) state that the audit effort ratio is calculated based on the actual minimum hour determined and find that it is positively correlated with firm size. Adeyemi and Fagbemi (2010) suggest that company size and business volume are important factors in audit quality for listed firms on the Nigerian Stock Exchange. Client interest tends to contradict the auditor's desire to maintain audit quality as Xinjun (2007) concludes that they are negatively related to the audit quality.

Further, Al-Thuneibat et al. (2011) also utilize firm size as a control variable in its audit quality study. In the context of regulatory theories, certain large public companies are required to be audited by a registered audit firm at BAPEPAM. Similarly, state-owned companies must be audited by BPK RI or audit firm which is registered with BPK RI. Based on the above observations, the following hypotheses are formulated:

$\mathrm{H}_{1 \mathrm{a}}$ : Client's size has a positive effect on audit quality-detecting misstatement.
$\mathrm{H}_{2 b}$ : Client's size has a positive effect on audit quality-reporting misstatement.

\section{Effect of Industrial Specialization on Audit Quality}

Audit firms that have many clients in a similar industry will be able to provide an indepth understanding of the unique audit risks arising from a particular industry. Audit firms having fewer clients in a specified industry may not have the critical mass to keep up with the pace of new developments in the industry (Wooten, 2003). Craswell et al. (1995) reported that industry experts set a premium price, which indicates the difference in quality pricing. The more clients an audit firm has in a particular industry, the better its reputation because it is considered to have successfully provided quality audit service within a particular industry type. Prior research indicates that audit cost for the big 8 auditors includes premiums relating to the brand name and industry specialization (Craswell et al. 1995),

The results of(Behn, Choi, \& Rang, (2008) indicate that high audit quality is derived from big 5 auditors and industry specialists from nonbig 5 auditors. This result is in line with Inaam, Khmoussi, \& Fatma, (2012) study stating that industry specialist auditors and big4 auditors are associated with low levels of earnings management. Besides, industry specialization may offset the negative effects of mandatory rotation on audit quality (Anis, 2014). Hogan (2009) suggests choosing a specific auditor to minimize audit costs. The results of this study provide evidence of differential risk-specific effects of clients on various types of auditors. Audit firms with higher client concentrations in certain industry classifications have higher quality levels because they have additional resources to utilize. In the context of regulatory theories, the decision of management to appoint auditors specializing in certain industries is in line with the Standards of Professional Public Accountants related to audit firm quality control standard (SPAP Per 31 March 2011 PSPM Section 200: 17000.1-17000.9 regarding personnel assignment and employment). Based on the above statement, the following hypothesis is raised:

$\mathrm{H}_{2 \mathrm{a}}$ : Industry specialization has a positive effect on audit quality-detecting misstatement.

$\mathrm{H}_{2 b}$ : Industry specialization has a positive effect on audit quality-reporting misstatement.

\section{Effect of Audit Quality on Audit fee}


Research related to audit quality and audit fees has been conducted, among others, by Choi, Kim, Kim, \& Zang (2010) suggesting that large local audit firms were able to charge higher audit service fees to their clients than smaller local audit firms. This indicates that the greater the size of the audit firm, the greater the audit service fees may be charged to the clients. In harmony with this, the results of Craswell et al. (1995) signify that audit fees imposed by big 8 auditors include premiums related to general brand names and industry specialization. Empirical results from the research of Sulong et al., (2013) implies that higher audit fees received by auditors may create a bond between the client and the auditor. In agreement with this, the results of the study by Hoitash et al. (2007) state that there is an economic bond between the auditor and the client, notwithstanding the consideration of the auditor's reputation itself. Anis's (2014) study states that high fee dependence harms arguments on the positive impact of mandatory rotation on audit quality. Hogan (2009) suggests that management trade-off the benefits of having a high-quality auditor with the costs and choose auditors that minimizes the sum of these costs, resulting in high-risk companies selecting lower quality audit firms.

Moreover, Deis and Giroux (1996) found lower costs in the first year of the concurrent audit without any major impact on the audit quality. This can be a strategy to be adopted by the management to replace its auditors annually to minimize audit costs.

Nevertheless, Wooten (2003) states that the outcome of audit quality is higher audit effort which translates to higher fees. This is in contrast to previous studies such as Hoitash et al., (2007) findings indicating a negative association between audit fees and audit quality. In the context of signaling theory, to obtain a higher fee, the audit firm (signal provider) provides signals to prospective clients and stakeholders (signal recipients) that the audio quality delivered by an audit firm can detect and report material misstatements made by clients. Based on the statement above, the following hypothesis is raised:

$\mathrm{H}_{3 \mathrm{a}}$ : Audit quality-detecting misstatement has a positive effect on audit fees.

$\mathrm{H}_{3 b}$ : Audit quality-reporting misstatement has a positive effect on audit fees

\section{Effect of Audit Quality on Reputation}

Deis and Giroux (1992) find that reputation and power conflicts are significant determinants of audit quality. This is in line with Hay and Davis (2004) stating that the size and reputation of an audit firm are substitutes for audit quality. Consistent with Craswell et al. (1995) conclusions, audit fees for big 8 audits include premiums related to general brand names and industry specialization. However, Hoitash et al. (2007) claim higher fees will create an economic bond between the auditor and the client and not as a result of the auditor's reputation itself. The auditor's reputation is based on the client's trust in the extent of monitoring and supervision carried out by the auditor (Watkins et al., 2004). The auditor's reputation will have a large effect on the credibility of the information and how reliable information will be perceived and closely related to market perceptions of the competence and objectivity possessed by the auditor. To achieve a good reputation, auditors must ensure high audit quality is produced and provide signals to stakeholders that their work meets the auditing industry standard of quality. This conforms with Wooten's (2003) model describing that outcome of audit quality is a good reputation.

In contrast to previous studies such as DeAngelo (1981), audit quality was the main criterion in building a good reputation hence auditors will strive to make efforts to ensure high audit quality is evident. Over time, auditors attempt to maintain the reputation they have built by deploying more experienced auditors to preserve its audit quality benchmark. In the context of signaling theory, to obtain a higher fee, the audit firm (signal provider) provides signals to prospective clients and stakeholders (signal recipients) that the audit quality delivered by an audit firm can detect and report material misstatements made by clients. We argue that this ability to detect and report misstatement would lead to the increased reputation of auditors, and, thus, the following hypothesis is raised:

$\mathrm{H}_{4 a}$ : Audit quality-detecting misstatement has a positive effect on reputation.

$\mathrm{H}_{4 b}$ : Audit quality-reporting misstatement has a positive effect on reputation.

\section{Effect of Audit Quality on Litigation}

To minimize litigation, auditors deployed in audit assignments must be competent, specialize in the industry they are assigned to, and utilize their professional proficiency to produce high audit work and signal to stakeholders that audit 
quality provided by the auditor attain a high benchmark. This statement is following the Wooten (2003) model which states that the outcome of audit quality is a lower level of litigation.

Litigation in audit quality research can be employed as a dependent variable and can also be an independent variable (Latham and Linville, 1998). They further state that although significant progress has been made in the field of auditing, areas such as independent roles, client screening and risk premium used in litigation prevention behavior, strategic decision analysis, the cost structure of litigation and other legal factors need to be considered further. Palmrose (1988) indicates that the non-big audit firms have a higher level of litigations than big eight audit firms. In the context of Indonesia, all audit firms that are subject to sanctions in the form of freezing or revocation of permits in 2017 are from the non-big audit firm. Results of Sun and Liu's (2010), (Memiş \& Çetenak, 2012), (Moazam, Muhammad, Corresponding, \& Khan, 2015), (Almarayeh et al., 2020) study indicate greater effectiveness of large $\mathrm{N}$ auditors than non- $\mathrm{N}$ auditors in terms of limiting the occurrence of income manipulation actions against clients that have higher legal liability risks than clients at lower risk of lawsuits. Besides, some researchers such as King and Schwartz (1999) find penalties imposed on audit firms introduce a "shock" that increased variability in auditors' choices of effort.

Further, Grant, Bricker, and Shiptsova (1996) support the continuation of the role of professional accounting bodies, such as AICPA in improving audit quality as the organization may initiate effective sanctions. The results of Brown and Raghunandan (1997) studies suggest that no litigation provides incentives for poor quality audit firms to enter the market and for firms that reduce fees resulting in lowering the audit quality (the other way around?). Besides, Kadous (2000) in his research states that to provide a higher quality audit the auditor should not be protected from legal liability in the event of an audit failure. In the context of signaling theory, the audit firm must signal to the stakeholders that audits performed by the audit firm are low litigation risk audits. Besides, the existence of several cases related to audit quality such as the Enron debacle and the background of this research formed the initial perception that the high level of litigations is a result of a low-quality audit. Based on the above statement, the following hypothesis is raised:
$\mathrm{H}_{5 \mathrm{a}}$ : Audit quality-detecting misstatement harms litigation.

$\mathrm{H}_{5 b}$ : Audit quality-reporting misstatement harms litigatio

\section{DATA AND METHODS}

This study utilizes a quantitative approach examining the effect of other services variables, such as audit tenure, audit firm size, and firm client size on audit quality. This research employed a survey method to collect data and used path analysis to explain the relationship between the above variables. The population in this study are accountants working as an external auditor residing in Indonesia because external auditors are responsible for audit quality (DeAngelo, 1981; Watkins et al., 2004). The sample in this study is the accountants who work as auditors in audit firms located in Jakarta, the capital of Indonesia. The selection of auditors located in the Jakarta area is due to the largest external auditor population (active IAPI members) having as many as 475 members out of a total 808 auditors or $58.79 \%$ (IAI, 2010). These external auditors conduct audits not only in Jakarta but also in other areas within Indonesia.

Purposive sampling is used based on the following criteria: (1) external auditor working in KAP (Public Accounting Office), (2) external auditor working in Jakarta area, and (3) external auditor with a minimum of one-year working experience. Primary data is used in this study. Data collection techniques used in this study is the collection of data using questionnaires.

The audit fees are measured using different proxies namely auditor reputation, experience, quality, and client's size. (adapted from Hoitash et al., 2007; Craswell et al., 1995.

A mail survey was used to gather data in this study. 304 questionnaires were distributed to the respondents in which 204 questionnaires were returned to the researcher. This gives a response rate of $67.11 \%$. Of the 204 responses, 168 of them were usable, as 28 respondents changed their address, 4 respondents were unknown, 2 respondents deceased, and 2 respondents were inactive. As a result, further analyses were carried out on the remaining 168 usable responses. Measurement of the variables used in this study are shown in table 1. 
The population in this study was banks in Indonesia. The sampling technique in this study was purposive sampling; the determination of samples with certain criteria following the objectives of the study. The criteria used are 1) the bank had gone public on the Indonesia Stock Exchange before 2009; 2) the bank published its
2009-2015 financial statements. Based on the sampling technique, the number of companies entering the sample was 30 banks. The source of data used secondary data taken from http: idx.co.id. The type of data was in the form of quantitative data and in the form of financial statement data

Tabel 1. Measurement of Variables

\begin{tabular}{|c|c|}
\hline Variable & Measurement \\
\hline IS & $\begin{array}{l}\text { Industry Specialization (IS) is measured by working periods and number of auditing tasks completed } \\
\text { in a specific industry (adapted from Craswell et al., 1995; Deis dan Giroux, 1992; modified) }\end{array}$ \\
\hline CS & $\begin{array}{l}\text { Client's size (CS) is measured by client's ability to negotiate and influence the audit results and the } \\
\text { degree of auditor's reliance on client (adapted from (Fernando et al,. 2010); Chen et al., 2010; Al- } \\
\text { Thuneibat et al., 2011; }\end{array}$ \\
\hline$A Q$ & $\begin{array}{l}\text { Audit quality (AQ) is measured by } 1 \text { ) compliance to audit standards and the auditor abilities to detect } \\
\text { misstatements by the client (detecting misstatement) and } 2 \text { ) the quality of audit report and auditor } \\
\text { ability report misstatements by their client (reporting misstatement) (Adapted from DeAngelo, 1981). }\end{array}$ \\
\hline$R$ & $\begin{array}{l}\text { Reputation (R) is measured by trust earned from community/public, banks, and other financial institu- } \\
\text { tions. (adapted from DeAngelo, 1981; Watkins et al., 2004) }\end{array}$ \\
\hline$L$ & $\begin{array}{l}\text { Litigation (L) is measured by audit failure, number of litigation, and differences auditing quality. } \\
\text { (Adapted from Palmrose, 1988; Venkataraman at al., 2008) }\end{array}$ \\
\hline
\end{tabular}

\section{RESULT}

Respondents in this study are presented in Table 2. Based on Table 2, it shows that Respondents are dominated by men. Based on industry specialists as measured by work periods and the number of audit tasks completed in the industry tends not to be on industry specialists. The majority of respondents are auditors, with the majority of respondents being senior auditors. Whereas from work experience shows that the average is still lack of experience, which is less than 3 years. While those who have more than 4 years experience only a few. The results of the description analysis are presented in table 2 . The test results for each variable show all valid (Table 3 ).

\begin{tabular}{lll} 
Table 2. the groups of respondent & \\
\hline Number of respondent & $\begin{array}{l}\text { Total in each } \\
\text { category }\end{array}$ & $\%$ \\
\hline $\begin{array}{l}\text { Gender: } \\
\text { Male }\end{array}$ & 91 & 55 \\
$\begin{array}{l}\text { Female } \\
\text { Industry specialist: }\end{array}$ & 77 & 45 \\
Yes & 13 & 7.74 \\
No & 155 & 92.26 \\
Role: & & 5,95 \\
Partner & 10 & 1,19 \\
Manager & 2 & 54,76 \\
Senior auditor & 92 & 38,09 \\
Junior auditor & 64 & \\
Work experience: & & 60.12 \\
< 3 years & 101 & 30.95 \\
3-4 years & 51 & 8,93 \\
> 4 years & 15 & \\
\hline
\end{tabular}

\begin{tabular}{|c|c|c|c|c|c|c|c|}
\hline \multirow[t]{2}{*}{ Variables } & \multicolumn{4}{|c|}{ Theoretical Range } & \multicolumn{2}{|c|}{ Actual Range } & \multirow{2}{*}{$\begin{array}{l}\text { Standard } \\
\text { Deviation }\end{array}$} \\
\hline & Min & Max & Mean & Min & $\operatorname{Max}$ & Mean & \\
\hline IS & 8 & 48 & 28 & 8 & 46 & 34.29 & 10.463 \\
\hline $\mathrm{CS}$ & 3 & 18 & 10.5 & 3 & 18 & 11.27 & 4.438 \\
\hline $\mathrm{AQ}$ & 12 & 72 & 42 & 48 & 69 & 57.05 & 5.430 \\
\hline $\mathrm{F}$ & 4 & 24 & 14 & 4 & 22 & 15.24 & 6.144 \\
\hline $\mathrm{R}$ & 5 & 30 & 17.5 & 5 & 30 & 19.59 & 7.682 \\
\hline $\mathrm{L}$ & 3 & 18 & 10.5 & 3 & 18 & 11.87 & 4.901 \\
\hline
\end{tabular}


Table 3. Average Variance Extracted (AVE) and AVE Root

\begin{tabular}{crcc}
\hline \multirow{2}{*}{ Variable } & $\begin{array}{c}\text { Average Variance } \\
\text { tracted (AVE) }\end{array}$ & AVE Root & Note \\
\hline CS & 0.962 & 0.981 & Valid \\
IS & 0.935 & 0.967 & Valid \\
DM & 0.673 & 0.820 & Valid \\
RM & 0.573 & 0.757 & Valid \\
F & 0.970 & 0.985 & Valid \\
R & 0.971 & 0.985 & Valid \\
L & 0.993 & 0.996 & Valid \\
\hline
\end{tabular}

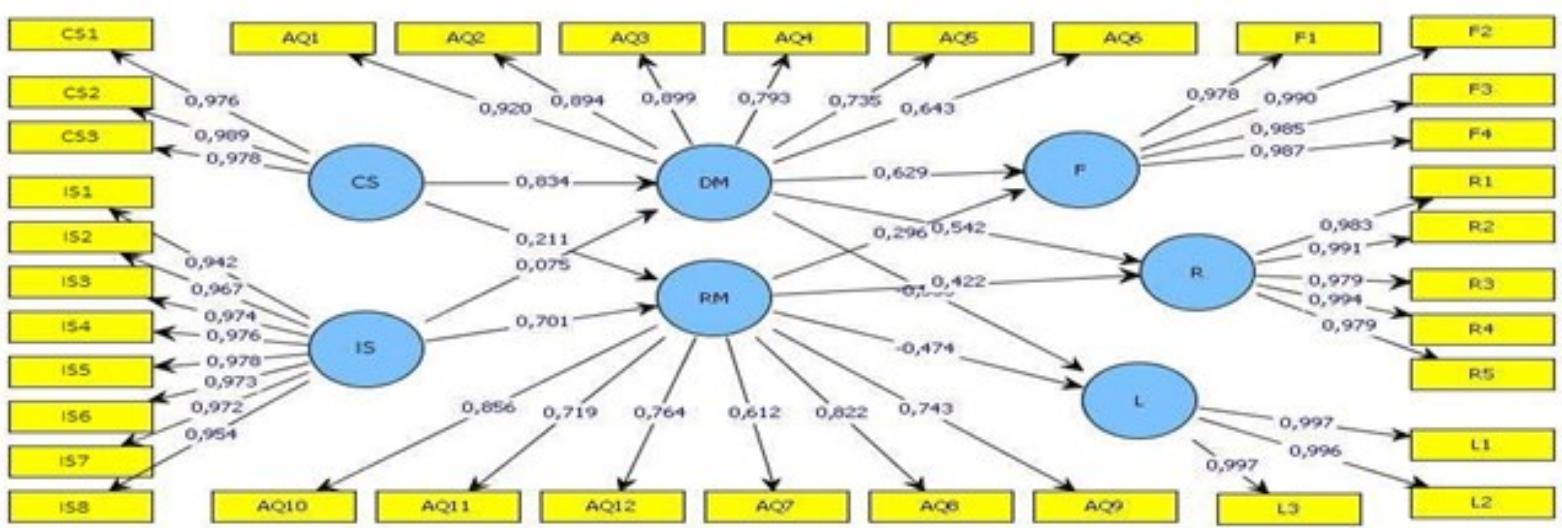

Figure 1. Full Model Research Using Path Analysis

Table 4. Interrelated Correlation

\begin{tabular}{llllllll}
\hline Variable & CS & IS & DM & RM & F & R & L \\
\hline CS & 1.000 & & & & & & \\
IS & 0.919 & 1.000 & & & & & \\
DM & 0.903 & 0.842 & 1.000 & & & & \\
RM & 0.856 & 0.896 & 0.797 & 1.000 & & & \\
F & 0.972 & 0.906 & 0.865 & 0.797 & 1.000 & \multirow{2}{*}{1.000} & \\
R & 0.986 & 0.919 & 0.878 & 0.854 & 0.962 & -0.914 & 1.000 \\
L & -0.920 & -0.895 & -0.932 & -0.915 & -0.884 & \\
\hline
\end{tabular}

Table 5. Statistical Test Results

\begin{tabular}{ccccccc}
\hline Hypothesis & Test & $\begin{array}{c}\text { Original sample } \\
\text { estimate }\end{array}$ & $\begin{array}{c}\text { Mean of sub } \\
\text { Samples }\end{array}$ & $\begin{array}{c}\text { Standard } \\
\text { deviation }\end{array}$ & T-Statistic & Note \\
\hline 1a & CS -> DM & 0.834 & 0.868 & 0.243 & $3.438^{* * *}$ & Supported \\
1b & CS -> RM & 0.211 & 0.244 & 0.138 & 1.528 & Not Supported \\
2a & IS -> DM & 0.075 & 0.038 & 0.240 & 0.313 & Not Supported \\
2b & IS -> RM & 0.701 & 0.666 & 0.134 & $5.252^{* * *}$ & Supported \\
3a & DM -> F & 0.629 & 0.604 & 0.106 & $5.937^{* * *}$ & Supported \\
3b & RM -> F & 0.296 & 0.322 & 0.109 & $2.724^{* * *}$ & Supported \\
4a & DM -> R & 0.542 & 0.519 & 0.128 & $4.232^{* * *}$ & Supported \\
$4 b$ & RM -> R & 0.422 & 0.447 & 0.121 & $3.482^{* * *}$ & Supported \\
$5 a$ & DM ->L & -0.555 & -0.548 & 0.062 & $8.962^{* * *}$ & Supported \\
$5 b$ & RM -> L & -0.474 & -0.484 & 0.052 & $9.116^{* * *}$ & Supported \\
\hline
\end{tabular}

Based on the results of correlation analysis shows that the correlation between Client size, Industry Specialization, Quality Audit-Detecting Mis-statements, Audit Quality-Reporting Misstatement, Audit Fees are positively correlated.
Whereas the relationship between litigation with Client size, with Industry Specialization, Audit Quality-Detecting Misstatement, Audit QualityReporting Misstatement, Audit Fees is negatively correlated (Table 4).

Based on the results of the path analysis, it 
shows that the Client size for Reporting Misstatements and Industry Specialist for DDTSelecting Misstatement is statistically unaffected (Hypotheses 2a and 2b). Whereas other hypotheses show the accepted hypothesis (Table 5).

\section{DISCUSSION}

\section{Effect of Client Size on Audit Quality}

In general, firm size have a positive effect on audit quality. The results indicated that firm size is significant and positively correlated with audit quality-detecting misstatement whereas there is no influence on the audit quality-reporting misstatement even though the direction is positive. The results of this test confirms that the larger the size of the client, the higher the audit quality produced by the audit firm both in terms of the ability to detect any errors made by the client. Larger companies generally possess more reliable internal control system that in turn facilitates the work undertaken by external auditors giving rise to lower audit risk and higher audit quality. This is in line with the findings of Elder et al., (2011) which states that both inherent risk and control risk originate from the client. If these risks are minimised, the risk of audit failure is low and audit quality enhances. In the context of the auditor-client factor analysis, the positive correlation indicates that the greater the size of the client, the higher the audit quality. This is because larger clients are able to remunerate employees with higher qualifications to establish a proper accounting system that ultimately lead to reliable documentation, accounting records and financial statements required for the audit process.

Al-Thuneibat et al. (2011) conclude reputable clients that produce credible financial statements coupled with management with high integrity and competence will bring about confidence and trust from the audit team. This corroborates the existence of factors other than the auditors themselves that may affect audit quality. This study also dismiss the assumption that audit quality depends on the quality of auditors such as Watkins et al. (2004) who claims audit quality is synonymous to auditors credibility. In the context of regulatory theory, large and public listed companies are required to be audited by an audit firm registered with BAPEPAM. Likewise for BUMN companies, they must be audited by the Republic of Indonesia BPK or audit firm that are registered with the Republic of Indonesia BPK (Fellmeth, 1985). This is carried out in order to improve au- dit quality and protect public interest (Stigler, 1971; Posner, 1974).

Specific results of the impact of client size on audit quality-detecting misstatement. This suggest that hypothesis 1a in which firm size has a positive effect on audit quality-detecting misstatement is supported. The results imply the larger the size of the client, the higher the audit quality produced by the audit firm. The size of the client has a positive effect on the audit quality-detecting misstatement. This demonstrate that the larger company, the higher the audit quality in terms of the ability to detect errors. The statistical test on relationship between company size and audit quality-reporting misstatement. This indicate that firm size has a positive effect on the audit quality-reporting misstatement is not supported. This imply that larger companies do not affect audit quality in terms of ability and willingness to report errors. The concerns at the beginning of this study that larger companies will influence the auditor opinion have not been proven.

\section{Effect of Industrial Specialization on Audit Quality}

Results of the impact of industry specialization on audit quality indicate a positive correlation as noted. Results of the effect of industry specialization on audit quality-detecting misstatement is not significant while industry specialization on the audit quality-reporting misstatement has a positive and significant association. The results of this study are consistent with Wooten's (2003) findings that auditing firms that have diverse clients in various industries will have a richer understanding of audit risks that are unique in a particular industry. Consistent with the results of research from Deis and Giroux (1992) accounting firms with higher client concentrations in specific industries will have higher levels of audit quality. In addition, Craswell et al. (1995) states the success and the reputation of an audit firm dependent upon the number of clients in a particular industry. The results of this study are in line with Behn et al. (2008) suggesting that high audit quality provided by industry specialists are necessarily derived from a big 5 auditor. These results also corroborates Inaam et al. (2012) study signifying that industry specialist auditors and big 4 auditors lead to the lower level of accrual earnings management. In addition, industry specialisation can offset the negative effects of mandatory rotation on audit quality (Anis, 2014). Hogan (1997) suggested choosing an industry 
specific auditor in which the results of his research provide evidence of customer-specific risk differential effects on various types of auditors. This can be done in order to minimize costs by choosing an industry specialist auditor rather than a big 4 auditor. In the context of the auditorclient factor analysis, the positive effect of industry specialization on audit quality indicates that because auditors have often audited clients in the same industry, auditors became more knowledgeable in that industry, resulting in improved audit quality. This confirms that industry specialist auditors affects audit quality. In the context of regulatory theory, the decision of audit firm management to make its auditors specializing in certain industries is in line with the Public Accountant Professional Standards related to audit firm quality control standards (SPAP Per 31 March 2011 PSPM Section 200: 17000.1-17000.9 concerning personnel assignments and employment). These standards are formulated to maintain high audit quality.

Statistical test results of the effect of industry specialization on audit quality-detecting misstatement is not significant. This shows that industry specialization has no impact on audit quality-detecting misstatement. The results of the effect of industry specialization on the audit quality-reporting misstatement This indicate that the higher number of clients in similar industries, the higher the audit quality. These results suggest that an industry specialist auditor leads to the higher audit quality. This signify that auditor's experience and capability accumulated over the years give rise to informed judgement in delivering an audit opinion.

\section{Effect of Audit Quality on Audit Fee}

The results of statistical tests on the effect of audit quality show a positive correlation with audit fees. Both audit quality-detecting misstatement and the audit quality-reporting misstatement are significant and positively related to audit fees. The results of this study confirm that the higher the audit quality, the higher the audit fees, due to increased audit effort. The results are consistent with Wooten (2003) conclusion that outcome of audit quality is greater audit effort.

In this study, the significant positive effect of audit quality-detecting misstatement on audit fees lies in the auditor's ability to detect material misstatements in the client's financial statements. Previous studies, amongst others, by Choi et al. (2010) suggest that large local audit firms are able to charge higher audit service fees to their clients than smaller local audit firms. Consistent with this, Craswell et al. (1995) state that audit fees for big 8 auditors comprise of premiums related to general brand names and industry specialization. Hence, we can conclude that the greater the size of audit firm, the greater the audit service fees charged to clients, resulting in higher audit quality.

\section{Effect of Audit Quality on Audit Firm Reputa- tion}

The results of statistical tests on the effect of audit quality (for audit quality-detecting misstatement and audit quality-reporting misstatement) on audit firm reputation in have a positive association. The results of this study imply that the higher the audit quality produced, the better the reputation of the audit firm. DeAngelo (1981) who examined the effect of reputation on audit quality discover that auditor size is a proxy of reputation and audit quality is not independent of auditor size. Deis and Giroux (1992) find that reputation and power conflicts are significant determinants of audit quality. In regards to professional auditing institutions, the size and the reputation of the audit firm act as substitute for auditor quality (Hay and Davis, 2004). On the contrary, Hoitash et al. (2007) claim that an economic bond between the auditor and the client exists regardless of the auditor's reputation. However, over time, auditors will strive to maintain their reputation by deploying experienced/ specialist auditors and as such able to command a premium over the non-Big 8 auditors (Craswell et al. , 1995). This is in line with Wooten (2003) findings that outcome of high audit quality is a better reputation. The auditor's reputation is based on the stakeholders trust in the power of monitoring or the strength of the supervision carried out by the auditor (Watkins et al., 2004). The auditor's reputation alone will have a large effect on the credibility of the information and how reliable information will be perceived and closely related to market perceptions of the competence and objectivity possessed by the auditor. In this study, a significant positive effect of audit-detecting quality misstatement on reputation lies in the auditor's ability to find errors in the client financial statements to build and maintain reputation. The demise of Arthur Anderson as a result of the Enron scandal demonstrate the need to maintain reputation by exercising due care and diligence to meet the standards of the auditing profession. In the 
context of signalling theory, the message provider must provide a message to the recipient of the message (Connelly et al., 2011), that to obtain a good reputation, the audit firm (signal provider) must provide signals to prospective clients and stakeholders (signal recipients) that the service provided by the audit firm is of high quality, maintaining or enhancing the reputation of the firm. As for the context of the auditor-client factor analysis, the positive effect shows that audit quality affects the auditor.

\section{Effect of Audit Quality on Litigation}

The statistical test between both audit quality-detecting misstatement, audit quality-reporting misstatement association and litigation produces a significant positive. This support this presumption that the higher the audit quality generated, the lower litigation risk. This result concurs with the Wooten (2003) model which states that the outcome of audit quality is lower litigation. Palmrose (1988) indicates that the non-big audit firms have higher level of litigations than big eight audit firms. In the context of Indonesia, all audit firms that are subject to sanctions in the form of freezing or revocation of permits in 2017 are from non-big audit firm. The freezing and revocation of audit firm permits in 2017 by the government is a preventive measure undertaken to minimize the litigation risk for audit firms and concurrently through professional institutions encourage public accountants to upgrade their capabilities by providing continuing education and training. Latham and Linville (1998) argue that although significant progress has been made in the field of auditing, further consideration needs to be taken into areas such as independent role of independence, client screening and risk premium used in litigation prevention behaviour, strategic decision analysis, cost structure of litigation and other legal factors. Results of Sun and Liu's (2010) study indicate greater effectiveness of large $\mathrm{N}$ auditors than non- $\mathrm{N}$ auditors in limiting the occurrence of income manipulation actions against clients that have higher legal liability risks than clients at lower risk of lawsuits. In addition to reducing litigation, some researchers such as King and Schwartz (1999) find penalties imposed on audit firms introduce a "shock" that can increased variability in auditors' choices of effort. Similarly, Grant et al. (1996) support the continuation of the role of professional accounting bodies such as AICPA in improving audit quality as the organization has effective sanctions.
In addition Kadous (2000) stated in situations when consequences of audit failure are more severe, auditors have to meet higher standards of care. The case of the buying and selling audit opinions involving BPK auditors shows that auditors are capable of detect errors and misstatements but reluctant to report it. As for the context of the auditor-client factor analysis, the negative correlation indicates if the auditors are not competent in discharging their duties, there is a higher risk of litigation in the future.

The results again suggest that the higher the audit quality produced, the lower litigation risk. In line with the results of this study, audit firms need to be conscious of the litigation risks by complying with the regulations to prevent any sanctions involving the freezing and revocation of permits by the Ministry of Finance. Sanctions applied in 2017 in which public accounting permits were frozen and revoked, among others, were due to the absence of audit work papers as evidence of audit activities and non-recording of audit activities including errors committed by clients, the basis of audit reports and disclosures of information errors and misstatements made by the client.

\section{CONCLUSIONS AND SUGGESTIONS}

This study has examined and provide empirical evidence of the impact of client size and industry specialization on audit quality and the effect of audit quality on audit fees, reputation and litigation both on audit-detecting misstatement quality and audit-reporting misstatement quality analysed based on client factors in perspective regulatory theory and signalling theory.

Based on the results obtained, the following conclusions can be drawn. The size of the client company has a positive effect on audit qualitydetecting misstatement. This proves that the greater the size of the client, the higher the audit quality produced by the auditor in terms of error detection ability. Proper internal control and data generated by a good internal control system invested by a large company accelerate and facilitate the auditor's work in detecting errors. The size of the client company does not affect the quality of audit reports. This is because reporting of errors is mainly determined by auditor independence. Industry specialization is significantly positively associated with the quality of auditreporting misstatement. This confirm the expectation that industry specialist auditors with their 
ample and relevant experience results in higher audit quality. The quality of audit-detecting misstatement and audit quality misstatements are significantly positively associated with audit fees. Higher quality is achieved when auditors are compensated fairly and adequately for their ability and efforts in ensuring the financial statements are free from material misstatements Auditdetecting misstatement quality and audit quality reporting errors is significantly positively associated with auditor's reputation. This outcome demonstrates that audit quality is synonymous with the reputation of the external auditor i.e. the higher quality the better the reputation of the auditor. Finally, audit-detecting misstatement quality and audit quality reporting errors has a significant negative effect on litigation. This proves that the higher the audit quality, the lower the litigation risk as a result of the auditor's competence to detect errors and express the correct opinion

The practical implications for this study can be summarised in following manner. For policymakers and regulators, this study supports the existence of regulations that set guidelines on minimum audit time-frame and the necessity for large and public listed firms to be audited by audit firms registered with OJK and BPK RI. For the clients, they may opt for auditor that charges lower fees but can provide a positive signal for stakeholders or choose an auditor that are registered with BPK or OJK because such audit firms are more acceptable by stakeholders. For the auditors, high quality audit is warranted to avoid the risk of litigation in addition to maintaining independence to gain trust from the public. This study has some limitations noted as follows. The absence in testing the client on the strength and effectiveness of the signal provided by the auditor and the signal captured by the client. Secondly, the number of respondents who filled out the questionnaire has only worked in the audit firms between one to two years hence respondents may lack experience and understanding the topic under research. Third, this study focusses on audit firms in Jakarta, Indonesia hence the institutional settings may differ in a different country and as such limit the potential to generalise the findings

\section{REFERENCES}

Adeyemi, S. B., and Fagbemi, T.O. (2010). Audit Quality, Corporate Governance and Firm Characteristics in Nigeria, International Journal of Business and Management. 5(5):
169-179.

Al-Thuneibat, A. A., Al Issa, R. T. I., \& Ata Baker, R. A. (2011). Do audit tenure and firm size contribute to audit quality?: Empirical evidence from Jordan. Managerial Auditing Journal, 26(4), 317-334. https://doi.org/ $10.1108 / 02686901111124648$

Almarayeh, T. S., Aibar-Guzmán, B., \& Abdullatif, M. (2020). Does audit quality influence earnings management in emerging markets? Evidence from Jordan. Revista de Contabilidad-Spanish Accounting Review, 23(1), 64-74. https://doi.org/10.6018/ rcsar.365091

Alsmairat, Y. Y., Yusoff, W. S., \& Ali, M. A. (2019). The effect of audit tenure and audit firm size on the audit quality: evidence from Jordanian auditors. International Journal of Business and Technopreneurship, 9(1), 15-24.

Anastasopoulos, N. P., \& Anastasopoulos, M. P. (2012). The evolutionary dynamics of audit. European Journal of Operational Research, 216(2), 469-476. https://doi.org/10.1016/ j.ejor.2011.06.003

Anis, A., (2014). Auditors' Perceptions of Audit Firm Rotation Impact On Audit Quality In Egypt. Accounting \& Taxation. 6(1): 105-120.

Arens, A. A., Elder, R.A. and Beasley, M.S. (2012). Auditing and Assurance Services, Fourteenth Edition, London: Pearson.

Atmojo, R. T., \& Sukirman. (2019). Effect of Tenure, Audit Specialization, and KAP's Reputation on the Quality of Audit Mediated by Audit Committees. 8(1), 66-73. https://doi.org/ 10.15294/aaj.v8i1.25538

Behn, B. K., Choi, J. H., \& Rang, T. (2008). Audit quality and properties of analyst earnings forecasts. Accounting Review, 83(2), 327-349. https://doi.org/10.2308/accr.2008.83.2.327

Benson, K., Clarkson, P. M., Smith, T., \& Tutticci, I. (2015). A review of accounting research in the Asia Pacific region. Australian Journal of Management, 40(1), 36-88. https://doi.org/ $10.1177 / 0312896214565121$

Brown, C. D., and Raghunandan,K. (1997). Audit Quality in Audits of Federal Programs by Non-Federal Auditors; A Reply, Accounting Horizons. 11(1): 72-75.

Carey, P., and Simnett, R. (2006). Audit Partner Tenure and Audit Quality. The Accounting Review. 81(3): 653-676.

Choi, J. H., Kim, C., Kim, J. B., \& Zang, Y. (2010). Audit office size, audit quality, and audit pricing. Auditing, 29(1), 73-97. 
https://doi.org/10.2308/aud.2010.29.1.73

Choi, J. H., Kim, J. B., Qiu, A. A., \& Zang, Y. (2012). Geographic proximity between auditor and client: How does it impact audit quality? Auditing, 31(2), 43-72. https://doi.org/10.2308/ajpt-10241

Connelly, B. L., Certo, S.T., Ireland, R.D., and C. R. Reutzel, C.R. (2011). Signaling Theory: A Review and Assessment. Journal of Management. 37(1): 39-67.

Cook, J. A., Kowaleski, Z. T., Minnis, M., Johnstone, K. M., Cook, J., \& Minnis, M. (2019). Auditors are Known by the Companies They Keep University of Notre Dame-Department of Accountancy University of Chicago-Booth School of Business Management Auditors are Known by the Companies They Keep *. Working Paper Chicago Booth No. 19-12, (19).

Craswell, Taylor, S. L. \& Francis, J. R. (1995). Auditor Brand Name Reputations and Industry Specializations. Journal of Accounting \& Economic, 20(3), 297-305.

DeAngelo, L. E., (1981). Auditor Size and Audit Quality, Journal of Accounting and Economic. 3: 183-199.

Deis, D. and Giroux, G. (1996). The effect of auditor changes on audit fees, audit hours, and audit quality. Journal of Accounting and Public Policy, 1996, vol. 15, issue 1, 55-76

Deis, D.R. Jr. and Gary A. Giroux, G. A. (1992). Determinants of Audit Quality in the Public Sector. The Accounting Review. Vol. 67, No. 3 (Jul., 1992), pp. 462-479

Deshmukh, A., \& Zhao, X. (2020). Audit Quality and Readability of the Annual Reports. International Journal of Strategic Decision Sciences, 11(1), 76-90. https://doi.org/ 10.4018/ijsds.2020010105

Durham, G. B. (2003). Likelihood-based specification analysis of continuous-time models of the short-term interest rate. Journal of Financial Economics, 70(3), 463-487. https://doi.org/10.1016/S0304405X(03)00207-1

Elder, R. J., M. S. Beasley, A. A. Arens, and Yusuf, A.A. (2011). Jasa Audit dan Assurance Pendekatan Terpadu (Adaptasi Indpnesia), Buku 1, Jakarta: Salemba Empat-Pearson Education

Fernando, G. D., A. M. A. Meguid,A.M.A. and Elder,R.J. (2010). Audit Quality Attributes, Client Size and Cost of Equity Capital, Review of Accounting and Finance.

Grant, Julia, Robert Bricker and Rimma Shiptsova.
(1996) Audit Quality and Profesional SelfRegulation; A Social Dilemma Perspective and Laboratory Investigation, Auditing; A Journal of Practice and Theory. 15 (1) Spring

Hay, D. \& Davis, D. (2004). The Voluntary Choice of an Auditor of Any Level of Quality. Auditing: A Journal of Practice and Theory, 23, 3753.

Hogan, C., and Martin. R.D. (2009). Risk shifts in the market for audits: An examination of changes in risk for - second tierl audit firms. Auditing: A Journal of Practice and Theory. 28(2): 93-118.

Hoitash, R., A. Markelevich and Barragato, C.A. (2007). Auditor Fees and Audit Quality, European Business Review. 19(1): 40-71.

Inaam, Z., Khmoussi, H., \& Fatma, Z. (2012). Audit Quality and Earnings Management in the Tunisian Context. International Journal of Accounting and Financial Reporting, 2(2), 17. https://doi.org/10.5296/ijafr.v2i2.2065

Kadous, K., (2000). The Effects of Audit Quality and Consequence Severity on Juror Evaluation of Auditor Responsibility for Plaintiff Losses, The Accounting Review. 75(3): 327341.

Kalabeke, W., Sadiq, M., \& Keong, O. C. (2019). Auditors Tenure and Financial Reporting Quality: Evidence from a Developing Country. International Journal of Asian Social Science, 9(5), 335-341. https://doi.org/ 10.18488/journal.1.2019.95.335.341

King, R. R.. and R. Schwartz. (1999). Legal Penalties and Audit Quality: An Experimental Investigation, Contemporary Accounting Research. 16(4): 685-710.

Latham, C. K., and Linville, M. (1998). A Review Of The Literature In Audit Litigation, Journal of Accounting Literature. 17: 175-213.

Laura, S., \& Darmawan, A. (2019). Does EcoEfficiency Reduce The Cost Of Equity Capital? Advances in Social Science, Education and Humanities Research, (Icaess), 343-347. https://doi.org/10.2991/icaess-19.2019.65

Leventis, S., and Caramanis, C. (2005). Determinants of Audit Time as a Proxy of Audit Quality, Managerial Auditing Journal. 20(5): 460-478.

Memiş, M. Ü., \& Çetenak, E. H. (2012). Earnings management, audit quality and legal environment: An international comparison. International Journal of Economics and Financial Issues, 2(4), 460-469.

Mgbame, C. O., Eragbhe, E., \& Osazuwa, N. P. 
(2012). Audit Partner Tenure and Audit Quality: An Empirical Analysis. European Journal of Business and Management, 4(7), 2222-2839.

Moazam, Muhammad, Corresponding, \& Khan. (2015). Quality and Audit Fees: Evidence from Pakistan. Research Journal of Finance and Accounting, 6(7), 1-12.

Oliverio, M. E., (2007). Promoting Audit Quality: U.K. Financial Reporting Council Discussion Paper, The CPA Journal. 77(2): 12-13.

Palmrose, Z., V., (1988). An Analysis of Auditor Litigation And Audit Service Quality, The Accounting Review. LXIII (1): 55-73.Peraturan Pengurus Ikatan Akuntan Publik Indonesia (IAPI) Nomor 2 Tahun 2016 tentang Penentuan Imbal Jasa Audit Laporan Kauangan.

Posner, R. A., 1974. Theories of Economics Regulation, Bell Journal of Economics and Management Science. 5 (2) : 335-358.

Stigler, G. J., (1971). The Theory of Economic Regulation, New York: Holt, Reinhart and Winston of Canada Ltd

Sulong, Z., Sultan, U., Abidin, Z., Gardner, J. C., Hussin, A. H., Kampus, U., Mcgowan, C. B. (2013). Managerial Ownership, Leverage, and Audit Quality Impact on Firm Performance: Evidence From The Malaysian Ace Market. Accounting \& Taxation, 5(1), 5970. https://doi.org/10.1080/15384101.2017. 1308617

Sun. J., and Liu, G. (2010). Client-specific Litigation Risk and Audit Quality Differentiation, Managerial Auditing Journal. 26(4): 300-316.

Tan, F., \& Yim, A. (2014). Can strategic uncertainty help deter tax evasion? An experiment on auditing rules. Journal of Economic Psychology, 40(35014), 161-174. https://doi.org/10.1016/j.joep.2012.11.005

Watkins, A. L., W. Hillison, and Morecroft, S.E. (2004). Audit Quality: A Synthesis of Theory and Empirical Evidence, Journal of Accounting Literature. 23: 153-193.

Wooten, T. C. (2003). Research About Audit Quality, The CPA Journal. 73(1): 48-51.

Xin-jun, N. (2007). Client Importance and Audit Quality: Evidence from A-Shares Capital Market Data of 2002-2005, Journal of Modern Accounting and Auditing. 3(11): 50-59. 